\title{
Dissolution of a mineral trioxide aggregate sealer in endodontic solvents compared to conventional sealers
}

\section{Hanan ALZRAIKAT \\ Nessrin Ahmad TAHA \\ Layla HASSOUNEH}

Jordan University of Science and Technology, Faculty of Dentistry, Department of

Conservative Dentistry, Irbid, Jordan.

Declaration of Interests: The authors certify that they have no commercial or associative interest that represents a conflict of interest in connection with the manuscript.

Corresponding Author:

Hanan Alzraikat

Email: hisa@just.edu.jo

DOI: 10.1590/1807-3107BOR-2016.vol30.0016

Submitted: May 08, 2015

Accepted for publication: Sep 02, 2015

Last revision: Sep 28, 2015

\begin{abstract}
The aim of this study is to evaluate the solubility of a Mineral Trioxide Aggregate sealer (MTA-Fillapex) compared with five other sealers, calcium hydroxide (Sealapex), resin (Realseal), zinc oxide-eugenol (Tubli-Seal), and two epoxy resins (AH-26 and AH-Plus), in chloroform and eucalyptoil in static and ultrasonic environments. Samples of each sealer were prepared $(n=180)$ and then divided into 12 groups that were immersed in solvents for 5 and $10 \mathrm{~min}$ in static and ultrasonic environments. The mean weight loss was determined, and the values were compared using Student's t-test, One-way ANOVA, and Tukey's HSD post-hoc test ( $\mathrm{p}$ 0.05). In chloroform, MTA-Fillapex, AH-26, and Sealapex displayed moderate solubility with no significant difference in dissolution ( $p=0.125$ ); however, their dissolution was significantly lower than that of AH-Plus ( $<0.001)$, which was almost fully dissolved after 10 minutes. Realseal was significantly less soluble than all sealers $(p<0.001)$. In eucalyptoil, MTA-Fillapex showed low solubility, as all of the sealers did, but Tubli-Seal was significantly more soluble than other sealers $(p<0.001)$. Using ultrasonic activation resulted in a significantly higher dissolution rate in chloroform for all sealers except MTA-Fillapex after $10 \mathrm{~min}(\mathrm{p}=0.226)$. In eucalyptoil, ultrasonic activation significantly increased the dissolution rate of all sealers except MTA-Fillapex after 5 and $10 \mathrm{~min}$, Sealapex at $10 \mathrm{~min}$, and AH-Plus at $5 \mathrm{~min}(\mathrm{p}>0.05)$. In conclusion, MTA-Fillapex was not sufficiently dissolved in either solvent. Ultrasonic activation had limited effectiveness on MTA-Fillapex dissolution, whereas it significantly increased the efficiency of solvents in dissolving a number of endodontic sealers.
\end{abstract}

Keywords: Endodontics; Root Canal Filling Materials; Solubility; Solvents.

\section{Introduction}

The goal of root canal treatment is to disinfect and clean the root canal system and to eventually seal the system and thereby prevent recontamination. A success rate of $97 \%$ has been reported for initial endodontic treatment, ${ }^{1}$ but failure still occurs during post-treatment. Because persistent or reintroduced microorganisms are the major cause of post-treatment disease, ${ }^{2}$ it can be assumed that the obturation material 
and root canal sealer were infected. Thus, the aim is to maximize their removal to optimize debridement and bacterial control.

The most widely used root canal filling material is gutta-percha in conjunction with a root canal sealer. Currently, several root canal sealers that are based on different formulas are available. Ørstavik ${ }^{3}$ categorized sealers into five different types according to their chemical formulation: zinc-oxide-eugenol based sealers, glass-ionomer based sealers, resin-based sealers, silicone-based sealers, and calcium hydroxide-based sealers. Recently, new sealers have been introduced into the market, including Bioceramic sealers and mineral trioxide aggregate-based sealers. ${ }^{4}$ Furthermore, sealers based on MTA are biocompatible and induce mineralization. ${ }^{5}$ They exhibit a stronger adhesiveness to dentin than do conventional zinc oxide/eugenol-based sealers, ${ }^{6}$ and they possess a sealing ability comparable to that of epoxy resin-based sealers. ${ }^{7}$

Several studies have suggested that chloroform is the most efficient solvent for most root filling materials compared with eucalyptoil, halothane, and xylol. ${ }^{8,9,10,11,12}$ Its safety and efficacy have also been proven over the years. ${ }^{13,14}$ However, chloroform has been reported to be potentially harmful when extruded into the periapical tissue. ${ }^{15}$ It can be tissue-toxic and has been shown to be potentially carcinogenic. Essential oils have been used in endodontics because of their proven safety, biocompatibility and non-carcinogenicity compared with organic solvents. ${ }^{13}$ Therefore, choosing the appropriate solvent necessitates the existence of a balance between its effectiveness and safety in usage. ${ }^{16}$

In an attempt to promote the efficacy of irrigation solutions and organic solvents, several methods have been devised to augment the irrigation process. The application of mechanical agitation and the activation of the solutions have been shown to improve the disinfection of root canals. ${ }^{17}$ However, there is a lack of literature evaluating the effect of ultrasonic activation on the efficiency of organic solvents during retreatment.

While root canal filling material should preferably display reasonable solubility in chemical solvents to facilitate retreatment, a high solubility of the material is undesirable because dissolution may result in gap formation both within the material and at the dentine material interface, which predispose the tooth to bacterial leakage over time; ${ }^{3}$ therefore, there are international specifications in this regard based on ANSI/ADA Specification $57 .^{18}$ This study is based on the fact that removing endodontic sealers from the root canal system by using solvents is a must for effective cleaning and disinfection.

Numerous studies have assessed the dissolving efficacy of organic solvents on various commonly

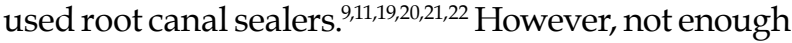
information is available regarding the solubility properties of the MTA-based root canal sealers in common endodontic solvents. Therefore, the aim of the present study is to assess the solubility of MTA-Fillapex compared with five sealers, calcium hydroxide (Sealapex), resin (Realseal), zinc oxide-eugenol (Tubli-Seal), and two epoxy resin sealers (AH-26 and AH-Plus), using two solvents (Chloroform, Eucalyptoil) in both static and dynamic environments. The null hypothesis tested was that MTA-Fillapex is less soluble than other tested sealers in both chloroform and eucalyptoil in static and ultrasonic environments.

\section{Methodology}

\section{Material selection}

The solubility of six root canal sealers (Table 1) was assessed in chloroform (99\% Chloroform, Carl Roth, Karlsruhe, Germany), eucalyptoil (Biodinamica Quim. e Farm. Ltda., Ibiporã, Brazil), and distilled water as a control solution.

\section{Sample molds design}

A stainless steel ring with an outer diameter of $10 \mathrm{~mm}$ and a thickness of $2 \mathrm{~mm}$ was used. A 4-mm-diameter centrally located hole was drilled in each mold for specimen placement, ${ }^{23}$ and a small hole was drilled peripheral to the sample hole to suspend the molds in the solution.

\section{Sealer sample preparation}

Prior to placing the mixed sealer samples in the stainless steel molds, all of the molds were cleaned with acetone for $15 \mathrm{~min}$ and weighed before use. Then, 
Table 1. Root canal sealers used in the study.

\begin{tabular}{|c|c|c|c|}
\hline Root canal sealer & $\begin{array}{l}\text { Chemical group } \\
\text { of sealer }\end{array}$ & Composition of sealer & Manufacturer \\
\hline MTA-Fillapex & MTA & $\begin{array}{l}\text { Salicylate resin, diluting resin, natural resin, bismuth trioxide, } \\
\text { nanoparticulated silica, MTA, pigments }\end{array}$ & $\begin{array}{l}\text { Angelus Soluções Odontológicas, } \\
\text { Londrina, PR, Brazil }\end{array}$ \\
\hline Sealapex & $\begin{array}{l}\text { Calcium } \\
\text { hydroxide based }\end{array}$ & $\begin{array}{c}\text { Base: Calcium Hydroxide, Sulfonamide, zinc oxide, zinc stearate, } \\
\text { Colloidal silica } \\
\text { Catalyst: Polymethylene salicylate, isobutyl Salicylate, resin, Barium } \\
\text { sulfate, Titanium oxide, Colloidal silica }\end{array}$ & Kerr, Salerno, Italy \\
\hline Tubli-Seal & $\begin{array}{l}\text { Zinc oxide } \\
\text { eugenol }\end{array}$ & $\begin{array}{c}\text { Base: Zinc oxide, Oleo resin, Bismuth trioxide, Thymol iodide, oils and waxes } \\
\text { Catalyst: Eugenol, Polymerized resin, Annidalin }\end{array}$ & Kerr, Salerno, Italy \\
\hline Realseal SE & Resin based & $\begin{array}{c}\text { Urethane dimethacrylate, polyethylene glycol dimethacrylate, } \\
\text { ethoxylated bisphenol-A dimethacrylate, Bisphenol glycidyl } \\
\text { dimethacrylate, barium borosilicte glass, barium sulfate, silica, calcium } \\
\text { hydroxide, Bismuth oxychloride with amines. }\end{array}$ & $\begin{array}{l}\text { SybronEndo Corporation, } \\
\text { Orange, USA }\end{array}$ \\
\hline $\mathrm{AH}-26$ & $\begin{array}{l}\text { Epoxy resin } \\
\text { based }\end{array}$ & $\begin{array}{c}\text { Powder: Bismuth oxide, Methenamine, Titanium oxide } \\
\text { Liquid: Bisphenol-A-diglycidylether }\end{array}$ & $\begin{array}{l}\text { Dentsply DeTrey GmbH, } \\
\text { Konstanz, Germany }\end{array}$ \\
\hline AH-Plus & $\begin{array}{l}\text { Epoxy resin } \\
\text { based }\end{array}$ & $\begin{array}{c}\text { Paste A: Bisphenol A epoxy resin, Bisphenol F epoxy resin, Calcium } \\
\text { tungstate, Zirconium oxide, Silica, Iron Oxide Pigments } \\
\text { Paste B: Dibenzyldiamine, Aminoadamantane, Tricyclodecane-diamine, } \\
\text { Calcium tungstate, Zirconium oxide, Silica, Silicon oil }\end{array}$ & $\begin{array}{l}\text { Dentsply DeTrey GmbH, } \\
\text { Konstanz, Germany }\end{array}$ \\
\hline
\end{tabular}

they were placed on a glass plate and slightly filled to excess with the freshly prepared sealer using a 1-mL syringe to prevent air entrapment. MTA-Fillapex and Realseal were supplied with a self-mixing tip, which was used for mixing the sealer and placing it into the metal rings directly from the tip. All sealers were mixed according to manufacturer's instructions. Because calcium hydroxide-based sealer requires moisture for setting; Sealapex was mixed with a spatula moistened with tap water. ${ }^{11}$ Ten minutes after the sealer mixtures were first prepared, they were left to set up for at least $48 \mathrm{~h}$ and up to $7 \mathrm{~d}$, as in the case of MTA-Fillapex and Sealapex, at $37^{\circ} \mathrm{C}$ and $100 \%$ humidity. The samples were considered to be completely set when a clean explorer did not penetrate the test sample. Excess material was trimmed off to the level of the mold surface using a scalpel. The samples were weighed on a digital scale to four decimal places of a gram.

\section{Experiment set-up}

\section{The first part of the experiment (static environment)}

At room temperature, each sealer sample was immersed in $20 \mathrm{~mL}$ of each solvent in a plastic tube with a screw cap (Chloroform, Eucalyptoil and distilled water as control group) for 5 and
$10 \min$ ( $n=15$ for each immersion period). After the specified immersion period, the sealer samples were removed from the solvents and allowed to dry for $24 \mathrm{~h}$ at $37^{\circ} \mathrm{C}$ before their weights were measured. Twenty-five empty sample molds were immersed in chloroform or in eucalyptoil for 5 and $10 \mathrm{~min}$ to ensure that the molds' suspension in solvents did not affect their weight. ${ }^{9}$

\section{The second part of the experiment (ultrasonic activation)}

Sample preparation was carried out as in the first part of the experiment $(\mathrm{n}=15$ for each immersion period), where each sealer sample was immersed in $20 \mathrm{~mL}$ of each solvent as mentioned previously. The plastic tubes containing the metal rings with the set sealer were subsequently placed in an ultrasonic chamber. This was done by placing the plastic tubes alternately in the ultrasonic chamber for one minute and then in a static environment during the second minute, and so on, throughout the designated immersion periods. The plastic tubes were placed in a Rack so they would not touch the floor of the ultrasonic chamber. At the end of each immersion period, the samples were removed and left to dry for $24 \mathrm{~h}$ at $37^{\circ} \mathrm{C}$.

Following the drying period, all samples were weighed three times, and the weight of the sealer 
was recorded to the nearest 0.0001 gramme. The amount of sealer removed from the specimen was determined as the difference between the original weight of the sealer and its final weight and measured to the nearest 0.0001 gramme. This difference in weight was calculated as a percentage of the original weight, recorded to the nearest $0.001 \%{ }^{9}$

The collected data were analyzed statistically using Statistical Software (SPSS for Windows, Release 6.1.2, IBM SPSS, Armonk, USA). Parametric tests were performed because the assumption of data being normally distributed was confirmed using the Leven's test. Independent sample t-test was used for pairwise comparisons, and one-way ANOVA with Tukey's HSD post-hoc test $(p<0.05)$ was used for multiple comparisons.

\section{Results}

The mean values and standard deviation of weight loss percent of sealers are shown in Table 2. No change in the weight of empty molds was reported in different immersion periods or environments in either solvent. In the distilled water control group, no sealer was dissolved in a static environment; however, in an ultrasonic environment, MTA-Fillapex and Sealapex showed significantly higher solubility after $10 \mathrm{~min}$, but their dissolution values in distilled water were low compared with those of organic solvents $(0.143 \%$ and $0.162 \%$, respectively; $\mathrm{p}<0.001)$.
Chloroform was a far more effective solvent for all root canal sealers compared with eucalyptoil in both static and ultrasonic environments (Figure). In addition, the solubility of sealers significantly increased as the immersion period increased from 5 to $10 \mathrm{~min}$, except for Realseal in chloroform in a static environment (Figure). The solubility of MTA-Fillapex in chloroform was comparable to that of Sealapex and AH-26 but was significantly lower than AH-Plus and Tubli-Seal $(p<0.001)$. Furthermore, the solubility of AH-Plus was significantly higher than that of all other sealers in chloroform in both the static and ultrasonic environments $(p<0.001)$ (Figure).

Generally, the efficiency of eucalyptoil in dissolving the various sealers was poor in both environments compared with chloroform, as shown in Figure 1. The solubility of MTA-Fillapex, AH-Plus, and Sealapex after 10 min was significantly higher than that of Realseal and AH-26 ( $p<0.05)$. Tubli-Seal was significantly more soluble than other sealers in eucalyptoil at $10 \mathrm{~min}$ of immersion, but it still showed a low solubility range. In contrast, $\mathrm{AH}-26$ was virtually insoluble with less than $1 \%$ weight loss after $10 \mathrm{~min}$ of immersion.

\section{Effect of ultrasonic activation on sealer dissolution}

In chloroform, ultrasonic activation during sealer immersion significantly increased sealer dissolution after $5 \mathrm{~min}$, except for Realseal and AH-26 ( $\mathrm{p}=0.819$,

Table 2. Mean values and standard deviation (SD) of sealer dissolution in Distilled water, Chloroform, and Eucalyptoil in static and ultrasonic environments.

\begin{tabular}{lccccccc}
\hline \multirow{2}{*}{$\begin{array}{l}\text { Root canal } \\
\text { sealer }\end{array}$} & Time & \multicolumn{2}{c}{ Distilled water } & \multicolumn{2}{c}{ Chloroform } & \multicolumn{2}{c}{ Eucalyptoil } \\
\cline { 3 - 8 } & & $\begin{array}{c}\text { Static (\%) } \\
\text { Mean (SD) }\end{array}$ & $\begin{array}{c}\text { Ultrasonic (\%) } \\
\text { Mean (SD) }\end{array}$ & $\begin{array}{c}\text { Static (\%) } \\
\text { Mean (SD) }\end{array}$ & $\begin{array}{c}\text { Ultrasonic (\%) } \\
\text { Mean (SD) }\end{array}$ & $\begin{array}{c}\text { Static (\%) } \\
\text { Mean (SD) }\end{array}$ & $\begin{array}{c}\text { Ultrasonic (\%) } \\
\text { Mean (SD) }\end{array}$ \\
\hline \multirow{2}{*}{ MTA-Fillapex } & $5 \mathrm{~min}$ & $0.0000(0.0000)$ & $0.0000(0.0000)$ & $8.2521(1.7175)$ & $11.9293(1.9527)$ & $3.0001(0.7763)$ & $2.9381(1.1206)$ \\
& $10 \mathrm{~min}$ & $0.0000(0.0000)$ & $0.1431(0.0003)$ & $18.0221(2.6439)$ & $20.4713(3.2557)$ & $4.2666(1.1239)$ & $4.3965(1.7271)$ \\
Sealapex & $5 \mathrm{~min}$ & $0.0000(0.0000)$ & $0.0000(0.0000)$ & $9.6648(2.6796)$ & $13.5091(1.8419)$ & $3.2717(0.9489)$ & $4.7707(2.2573)$ \\
& $10 \mathrm{~min}$ & $0.0000(0.0000)$ & $0.1622(0.0009)$ & $21.1981(3.3247)$ & $27.0490(4.1278)$ & $4.8847(1.4484)$ & $5.7582(1.5581)$ \\
Realseal & $5 \mathrm{~min}$ & $0.0000(0.0000)$ & $0.0000(0.0000)$ & $6.8663(2.2195)$ & $6.7082(1.4450)$ & $1.3310(0.5559)$ & $4.8431(1.7197)$ \\
& $10 \mathrm{~min}$ & $0.0000(0.0000)$ & $0.0000(0.0000)$ & $6.8445(2.3839)$ & $12.4938(1.5978)$ & $3.3424(1.0234)$ & $11.0623(2.2372)$ \\
Tubli-Seal & $5 \mathrm{~min}$ & $0.0000(0.0000)$ & $0.0000(0.0000)$ & $20.5879(4.1845)$ & $24.5932(4.8071)$ & $2.8478(0.7118)$ & $4.9254(1.1626)$ \\
& $10 \mathrm{~min}$ & $0.0000(0.0000)$ & $0.0000(0.0000)$ & $52.0731(8.3568)$ & $63.3796(14.6160)$ & $8.1419(1.7268)$ & $11.6392(6.2900)$ \\
AH-26 & $5 \mathrm{~min}$ & $0.0000(0.0000)$ & $0.0000(0.0000)$ & $9.6467(1.8443)$ & $10.6571(2.6931)$ & $0.1665(0.0313)$ & $0.6912(0.3226)$ \\
& $10 \mathrm{~min}$ & $0.0000(0.0000)$ & $0.0000(0.0000)$ & $19.5736(3.3206)$ & $23.2361(2.9783)$ & $0.3507(0.1464)$ & $1.9240(0.7772)$ \\
AH-Plus & $5 \mathrm{~min}$ & $0.0000(0.0000)$ & $0.0000(0.0000)$ & $71.0912(16.6769)$ & $99.5987(0.4258)$ & $4.0956(1.3080)$ & $4.4350(2.1001)$ \\
& $10 \mathrm{~min}$ & $0.0000(0.0000)$ & $0.0000(0.0000)$ & $99.3285(0.6671)$ & $99.8871(0.1349)$ & $5.3204(1.7283)$ & $11.6647(2.5589)$ \\
\hline
\end{tabular}




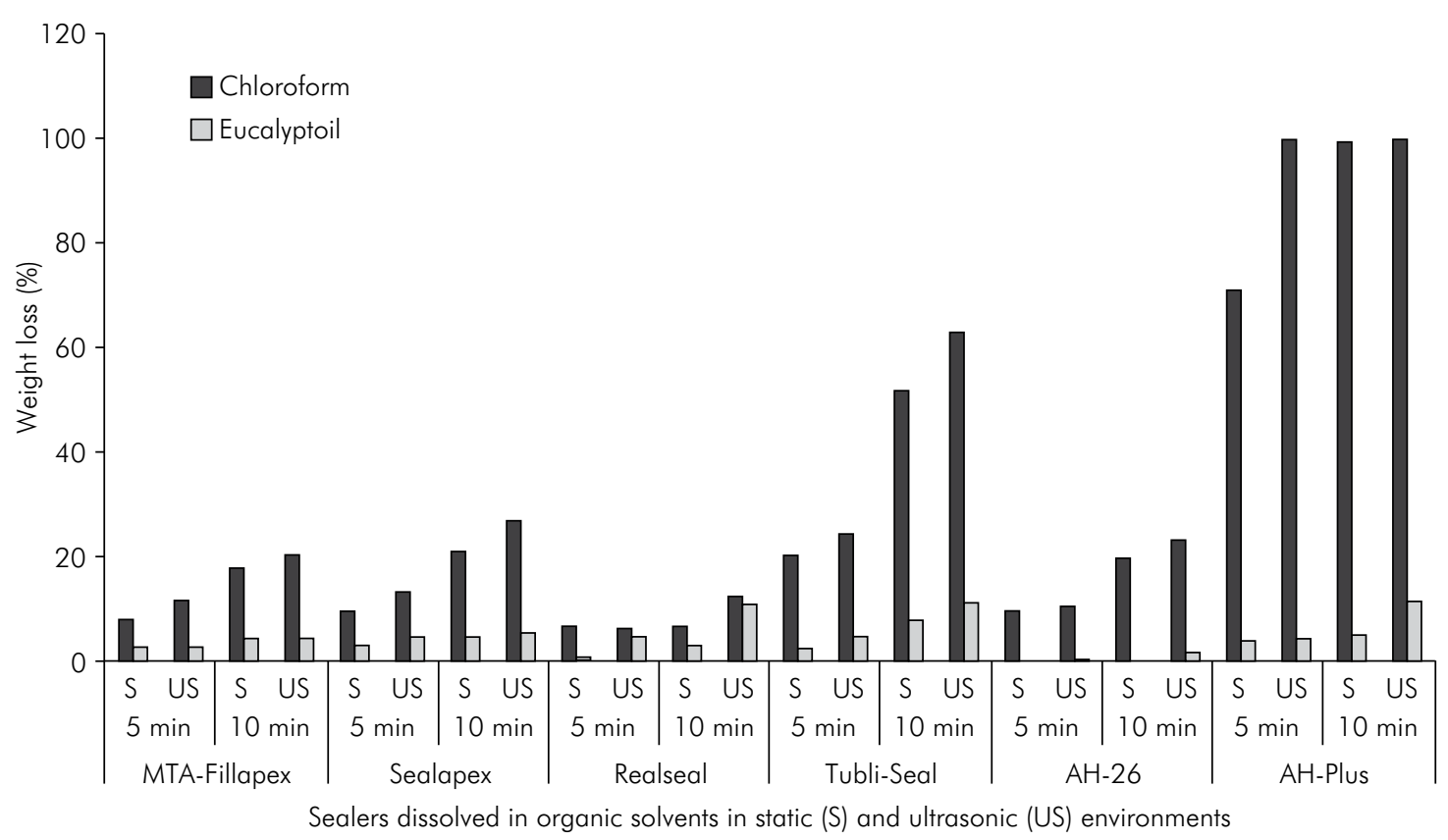

Figure. Dissolution of sealers in chloroform and eucalyptoil in static and ultrasonic environments for 5-and 10-min immersion periods.

0.241 , respectively). However after $10 \mathrm{~min}$, ultrasonic activation did not affect the dissolution of MTA-Fillapex but resulted in a significantly higher dissolution rate for all other tested sealers $(\mathrm{p}<0.05)$ (Figure).

In eucalyptoil, MTA-Fillapex did not show a statistically significant difference when it was dissolved in an ultrasonic environment compared with a static environment in both immersion periods (Figure). However, the remaining sealers reported significantly greater dissolution after ultrasonication, except for Sealapex at $10 \mathrm{~min}$ and AH-Plus at 5 minutes.

\section{Discussion}

The null hypothesis that was postulated in the current study was rejected. All of the tested sealers in the current study showed significantly higher dissolution in chloroform than in eucalyptoil. In chloroform, MTA-Fillapex showed a lower dissolution rate than did AH-Plus and Tubli-Seal but a similar dissolution rate to $\mathrm{AH}-26$ and Sealapex. Similar results were seen when ultrasonic activation was used.

The method used in the current study to assess sealer dissolution was adopted due to its simplicity and reproducibility and fairly low cost. However, several clinically relevant parameters, such as root canal dimensions, solvent temperature, and contact time, could not be replicated. It can be assumed that the contact area in the current study between the sealer and solvent solution was higher than the actual contact area with the sealer within the confines of the root canal anatomy, which may imply a lower dissolution in a clinical setting. Nonetheless, it facilitated the comparison of the results with previously published data. 9,11,21,22,23

In the distilled water control group and in an ultrasonic environment, MTA-Fillapex and Sealapex showed a significantly higher degree of solubility after 10 min of immersion, which may have occurred because both sealers release $\mathrm{Ca}^{+2}$ ions when dissolved in water. This was described in previous studies that investigated the ion release of MTA-Fillapex and Sealapex. ${ }^{24,25,26}$

Borges et al. ${ }^{26}$ reported that the solubility of MTA-Fillapex in deionized water was high (14.89\%) and comparable to that of Sealapex, which is higher than the ANSI/ADA ${ }^{18}$ requirements of $3 \%$ of the total mass. This solubility is higher than the value reported in the current study; the difference is due to the different experimental method and sample dimensions employed. Borges et al. ${ }^{26}$ stored the samples in water for 7 days before weighing to test the 
degree of dissolution of sealers, which is considered a negative point in terms of the long-term apical and coronal seal that is crucial for the long-term success of root canal therapy. In contrast, this study aimed to evaluate the dissolution of sealers in chemical solvents as part of the endodontic retreatment procedure, for which maximum solubility is required to optimize disinfection of the canals. Therefore, the samples were kept in water for 5 or 10 min only to simulate clinical procedures. The dissolution over this short storage period was thus not comparable to that observed for 7 days of storage, as reported by Borges et al. ${ }^{26}$

Overall, the results concerning the solubility of the sealers tested in the current study in chloroform and eucalyptoil are in good agreement with previously published studies. ${ }^{9,11,19}$ According to our results, chloroform was a far more effective solvent than eucalyptoil for MTA-Fillapex and all of the other tested sealers. In a static environment, the solubility of MTA-Fillapex in chloroform was similar to that of Sealapex and AH-26 but significantly lower than that of AH-Plus and Tubli-Seal. This could be explained by the resinous component in the MTA-Fillapex. ${ }^{4}$

AH-Plus and Tubli-Seal were highly soluble in chloroform at an exposure time of $10 \mathrm{~min}$, which is in agreement with other studies.,19,21 $\mathrm{AH}-26$ was found to be significantly less soluble than AH-Plus. This finding agrees with the finding of Hansen, ${ }^{27}$ who reported that chloroform did not have a noticeable dissolving effect on AH-26; similarly, Schäfer and Zandbiglari ${ }^{9}$ found a great difference in the dissolution rate between AH-26 and AH-Plus. This discrepancy might be related to the difference in the size of their resinous particles. It could also be due to differences in their manufacturing details, which most manufacturers do not disclose.

Epiphany sealer, which has a similar chemical composition to Realseal but a different brand name, has been reported to have a good solubility in chloroform after a 10 -min immersion. ${ }^{19}$ However, this disagrees with our results concerning Realseal. This discrepancy might be due to the difference in methodologies used. Furthermore, Bordumulu et al. ${ }^{19}$ removed the sealer samples from the molds and then immersed them in the solvent, which provided a three-dimensional exposure of the sealer to the solvents. However, in this present study, only 2 surfaces of the sealer were exposed to the solvent.

Only Tubli-Seal was partially dissolved by eucalyptoil. This might have occurred because most ZnOE-based cements have a high concentration of colophony in their composition to improve their adhesive properties. Colophony is a vegetable resin that is composed of approximately $90 \%$ of resinous acids and is soluble in solvents that are commonly used in endodontic retreatment. ${ }^{22}$

No previous studies have investigated the effect of ultrasonic activation on the dissolution of root canal sealers. In the current study, the plastic tubes containing the metal rings with the set sealer were placed in an ultrasonic chamber. The agitation effect of the ultrasonic activation was noted by the vibrations seen in the solvent solution surrounding the sealer samples in the plastic tubes. In the root canal setting, the bond strength of the sealer to dentin may further affect the degree of dissolution by ultrasonic agitation; however, the methodology is acceptable for the sake of comparison between different sealers.

Applying ultrasonic activation converts electric energy into waves with certain frequencies. This energy generates a high movement of fluid in a circular action around the vibrating instrument. This rapid movement occurs inside the canal space when activating an irrigant and should induce its cleaning and dissolving efficiency. In addition, ultrasonically activating a solution can cause cavitation (i.e., the development and collapse of bubbles in a liquid medium followed by the release of energy) of the irrigant, which also improves its efficiency. ${ }^{28}$ This explains our results, which showed a significantly higher efficiency of the tested solvents in dissolving root canal sealers when using ultrasonic activation.

Generally, immersing sealers in organic solvents for 10 min resulted in a significantly increased dissolution of sealers in both static and ultrasonic environments compared with $5 \mathrm{~min}$, which is in agreement with previous studies., ${ }^{911,19,21}$ Schäfer and Zandbiglari ${ }^{9}$ reported a remarkable increase in sealer solubility in chloroform and eucalyptoil with time, especially after a 5-min immersion period. That result excludes 
AH-Plus and AH-26 in eucalyptoil, which showed very low solubility at all immersion periods. Similarly, Bordumulu et al. ${ }^{19}$ reported no significant difference between 2 and 5 min of immersion in chloroform and eucalyptoil for AH-Plus, Ketac-Endo and Epiphany, but the 10-min immersion period showed a significantly higher dissolution rate compared with 2 and $5 \mathrm{~min}$ immersion in either solvent. In contrast, Martos et al. ${ }^{22}$ found no statistically significant difference in the dissolution of 3 different sealers (Sealer 26, Endofill and RoekoSeal) when they were immersed for 2 and $10 \mathrm{~min}$ in eucalyptoil.

The results of this study showed that the use of an ultrasonic activation or the dissolution of MTA-Fillapex in organic solvents for longer periods of time might aid in obtaining a higher dissolution rate for this sealer. Compared with the other sealers that were tested in the current study, its dissolution is comparable to that of AH-26 but is still considered low compared with commonly used sealers such as AH-Plus. Therefore,

\section{References}

1. Friedman S, Mor C. The success of endodontic therapy--healing and functionality. J Calif Dent Assoc. 2004;32(6):493-503.

2. Nair PN, Sjogren U, Krey G, Sundqvist G. Therapy-resistant foreign body giant cell granuloma at the periapex of a root-filled human tooth. J Endod. 1990;16(12):589-95. doi:10.1016/S0099-2399(07)80202-0

3. Ørstavik DAG. Materials used for root canal obturation: technical, biological and clinical testing. Endod Topics. 2005;12(1):25-38. doi: 10.1111/j.1601-1546.2005.00197.x

4. Assmann E, Scarparo RK, Bottcher DE, Grecca FS. Dentin bond strength of two mineral trioxide aggregate-based and one epoxy resin-based sealers. J Endod. 2012;38(2):219-21. doi:10.1016/j.joen.2011.10.018

5. Gomes-Filho JE, Watanabe S, Bernabe PF, Costa MTC. A mineral trioxide aggregate sealer stimulated mineralization. J Endod. 2009;35(2):256-60. doi:10.1016/j.joen.2008.11.006

6. Huffman BP, Mai S, Pinna L, Weller RN, Primus CM, Gutmann JL, et al. Dislocation resistance of ProRoot Endo Sealer, a calcium silicate-based root canal sealer, from radicular dentine. Int Endod J. 2009;42(1):34-46. doi:10.1111/j.1365-2591.2008.01490.x

7. Weller RN, Tay KC, Garrett LV, Mai S, Primus CM, Gutmann $\mathrm{JL}$, et al. Microscopic appearance and apical seal of root canals filled with gutta-percha and ProRoot Endo Sealer this finding should be considered when attempting to use MTA-Fillapex sealer in clinical cases.

\section{Conclusions}

Within the limitations of this study, the following conclusions can be drawn:

a. Chloroform presented a superior solvent effect compared with eucalyptoil, with a significant dissolution of tested sealers.

b. Realseal displayed the lowest solubility in chloroform, whereas in eucalyptoil, AH-26 was the least soluble of the tested sealers.

c. Generally, ultrasonic activation significantly increased the efficiency of chloroform but not eucalyptoil in dissolving sealers.

\section{Acknowledgments}

This research was supported by the Research Deanship, Jordan University of Science and Technology in grant number (2012-77)

after immersion in a phosphate-containing fluid. Int Endod J. 2008;41(11):977-86. doi:10.1111/j.1365-2591.2008.01462.x

8. Hunter KR, Doblecki W, Pelleu GB Jr. Halothane and eucalyptol as alternatives to chloroform for softening gutta-percha. J Endod. 1991;17(7):310-1. doi:10.1016/S0099-2399(06)81696-1

9. Schäfer E, Zandbiglari T. A comparison of the effectiveness of chloroform and eucalyptus oil in dissolving root canal sealers. Oral Surg Oral Med Oral Pathol Oral Radiol Endod. 2002;93(5):611-6. doi:10.1067/moe.2002.121899

10. Wennberg A, ØRstavik D. Evaluation of alternatives to chloroform in endodontic practice. Endod Dent Traumatol. 1989;5(5):234-7.

11. Whitworth JM, Boursin EM. Dissolution of root canal sealer cements in volatile solvents. Int Endod J. 2000;33(1):19-24. doi:10.1046/j.1365-2591.2000.00266.x

12. Carpenter MT, Sidow SJ, Lindsey KW, Chuang A, McPherson JC 3rd. Regaining apical patency after obturation with gutta-percha and a sealer containing mineral trioxide aggregate. J Endod. 2014;40(4):588-90. doi:10.1016/j.joen.2013.10.020

13. Magalhaes BS, Johann JE, Lund RG, Martos J, Del Pino FA. Dissolving efficacy of some organic solvents on gutta-percha. Braz Oral Res. 2007;21(4):303-7. doi:10.1590/S1806-83242007000400004

14. McDonald MN, Vire DE. Chloroform in the endodontic operatory. J Endod. 1992 Jun;18(6):301-3. 
15. Barbosa SV, Burkard DH, Spangberg LS. Cytotoxic effects of gutta-percha solvents. J Endod. 1994;20(1):6-8.

16. Schuur AH, Moorer WR, Wesselink PR. [Solvents for the removal of gutta-percha from root canals. 2. Side effects of chloroform, halothane and xylene]. Ned Tijdschr Tandheelkd. 2004;111(8):303-6. Dutch.

17. Rodig T, Bozkurt M, Konietschke F, Hulsmann M. Comparison of the Vibringe system with syringe and passive ultrasonic irrigation in removing debris from simulated root canal irregularities. J Endod. 2010;36(8):1410-3. doi:10.1016/j.joen.2010.04.023

18. American National Standards Institute. American Dental Association. Specification no 57 endodontic sealing material. Chicago (USA): ADA Publishing; 2000.

19. Bodrumlu E, Er O, Kayaoglu G. Solubility of root canal sealers with different organic solvents. Oral Surg Oral Med Oral Pathol Oral Radiol Endod. 2008;106(3):e67-9. doi:10.1016/j.tripleo.2008.05.007

20. Erdemir A, Adanir N, Belli S. In vitro evaluation of the dissolving effect of solvents on root canal sealers. J Oral Sci. 2003;45(3):123-6.

21. Martos J, Bassotto AP, Gonzalez-Rodriguez MP, Ferrer-Luque CM. Dissolving efficacy of eucalyptus and orange oil, xylol and chloroform solvents on different root canal sealers. Int Endod J. 2011;44(11):1024-8. doi:10.1111/j.1365-2591.2011.01912.x
22. Martos J, Gastal MT, Sommer L, Lund RG, Del Pino FA, Osinaga PW. Dissolving efficacy of organic solvents on root canal sealers. Clin Oral Investig. 2006;10(1):50-4. doi:10.1007/s00784-005-0023-2

23. Keles A, Koseoglu M. Dissolution of root canal sealers in EDTA and NaOCl solutions. J Am Dent Assoc. 2009;140(1):74-9; quiz 113. doi:10.14219/jada.archive.2009.0021

24. Kuga MC, Campos EAd, Viscardi PH, Carrilho PZ, Xaviér FC, Silvestre NP. Hydrogen ion and calcium releasing of MTA Fillapex ${ }^{\circledR}$ and MTA-based formulations. RSBO Rev Sul-Bras Odontol RSBO (Online). 2011 Jul-Sep [cited 201509 28];8(3):271-6. Available in: http://www.redalyc.org/articulo.oa?id=153021326005

25. Duarte MA, Demarchi AC, Giaxa MH, Kuga MC, Fraga SC, Souza LC. Evaluation of $\mathrm{pH}$ and calcium ion release of three root canal sealers. J Endod. 2000;26(7):389-90.

26. Borges RP, Sousa-Neto MD, Versiani MA, Rached-Junior FA, De-Deus G, Miranda CE, et al. Changes in the surface of four calcium silicate-containing endodontic materials and an epoxy resin-based sealer after a solubility test. Int Endod J. 2012;45(5):419-28. doi:10.1111/j.1365-2591.2011.01992.x

27. Hansen MG. Relative efficiency of solvents used in endodontics. J Endod. 1998;24(1):38-40. doi:10.1016/S0099-2399(98)80211-2

28. Ahmad M, Roy RA, Kamarudin AG. Observations of acoustic streaming fields around an oscillating ultrasonic file. Endod Dent Traumatol. 1992;8(5):189-94. 